\title{
Ongoing outbreak of dengue type 1 in the Autonomous Region of Madeira, Portugal: preliminary report
}

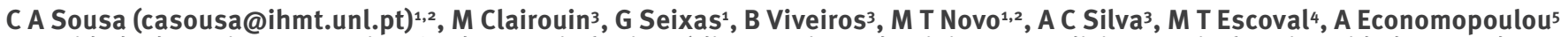

1. Unidade de Ensino e Investigação de Parasitologia Médica, Instituto de Higiene e Medicina Tropical, Universidade Nova de Lisboa, Lisbon, Portugal

2. Unidade de Parasitologia e Microbiologia Médicas, Instituto de Higiene e Medicina Tropical, Universidade Nova de Lisboa, Lisbon, Portugal

3. Departamento de Promoção e Proteção da Saúde, Instituto de Administração da Saúde e Assuntos Sociais, Autonomous Region Madeira, Portugal

4. Portuguese Haemovigilance System, Blood and Transplantation Portuguese Institute, Lisbon, Portugal

5. European Centre for Disease Prevention and Control (ECDC), Stockholm, Sweden

Citation style for this article:

Sousa CA, Clairouin M, Seixas G, Viveiros B, Novo MT, Silva AC, Escoval MT, Economopoulou A. Ongoing outbreak of dengue type 1 in the Autonomous Region of Madeira, Portugal: preliminary report. Euro Surveill. 2012;17(49):pii=20333. Available online: http://www.eurosurveillance.org/ViewArticle.aspx?Articleld=20333

Article submitted on 19 November 2012 / published on 6 December 2012

Following the identification of two autochthonous cases of dengue type 1 on 3 October 2012, an outbreak of dengue fever has been reported in Madeira, Portugal. As of 25 November, 1,891 cases have been detected on the island where the vector Aedes aegypti had been established in some areas since 2005. This event represents the first epidemic of dengue fever in Europe since 1928 and concerted control measures have been initiated by local health authorities.

On 3 October 2012, two autochthonous cases of dengue fever were laboratory confirmed in the Autonomous Region of Madeira (RAM), Portugal, following clinical suspicion of dengue, i.e. sudden onset of fever and influenza-like symptoms in patients without travel history to dengue-endemic regions. Laboratory tests performed by the National Institute of Health in Lisbon identified dengue virus serotype 1 (DENV-1) as causing agent. As of 25 November, the Institute of Health and Social Affairs (Instituto de Administração da Saúde e Assuntos Sociais, IASAUDE, RAM) in Madeira reported 1,891 cases of dengue fever. In this preliminary report we highlight the main features of the outbreak and the control measures taken.

\section{Background}

Dengue is a vector-borne disease caused by a flavivirus with four distinct serotypes (DEN-1-4). The most competent mosquitoes species for disease transmission are Aedes aegypti (Linnaeus, 1762) and Ae. albopictus (Skuse, 1894) [1]. The last outbreak of dengue in Europe occurred in 1928, in Greece [2] but imported cases of dengue fever in travellers returning from endemic countries are often reported [2-6]. Additionally, sporadic autochthonous cases were recorded recently in areas of France and Croatia where Ae. albopictus is present $[7,8]$.
Madeira is the main island of the Autonomous Region of Madeira, a Portuguese territory with 262,302 inhabitants [9]. It is located at around $1,000 \mathrm{~km}$ from mainland Portugal and around $500 \mathrm{~km}$ from the northern African coast. The other inhabited island of the Region is Porto Santo with 5,483 inhabitants [9]. The climate is temperate Mediterranean, with little temperature variation throughout the year [10]. Ae. aegypti was first identified on Madeira in 2005, in Santa Luzia parish of Funchal city [11].

\section{Epidemiological and clinical findings}

After the detection of the first two autochthonous dengue fever cases on 3 October 2012, active case finding was initiated and the following case definition has been used since:

A probable case should meet both clinical and epidemiological criteria outlined hereafter.

Clinical criteria comprised acute onset of fever and at least two of the following symptoms and signs: headache, retro-orbital pain, myalgia, arthralgia, exanthema, haemorrhagic manifestations or leucopoenia.

Epidemiological criteria are residing in or having visited a dengue-affected area during the 21 days prior to onset of symptoms. Currently, the whole island is considered as 'affected area' which means that the epidemiological criterion is met for all cases occurring on Madeira.

A confirmed case is defined as a probable case with at least one of the following laboratory results: (i) presence of dengue-virus-specific IgM antibodies in blood or cerebrospinal fluid (CSF); (ii) significant increase in the concentration of dengue-virus-specific IgG antibodies (seroconversion), or; (iii) detection of dengue 


\section{FIGURE 1}

Notified dengue fever cases by week, Madeira, Portugal, 3 October-25 November $2012(n=1,891)$

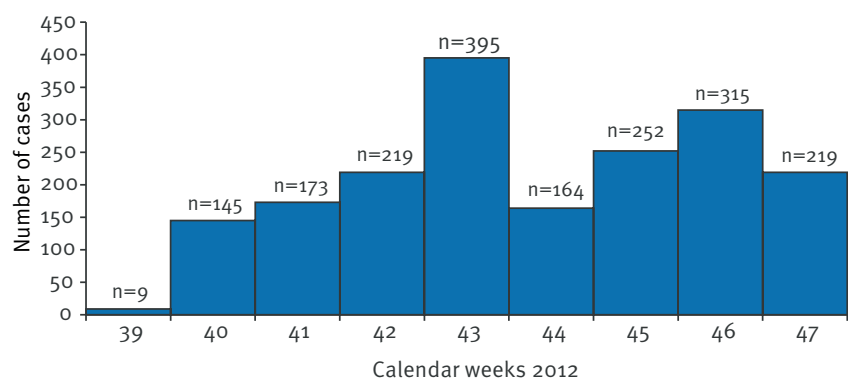

Source: Instituto de Administração da Saúde e Assuntos Sociais, Autonomous Region of Madeira, Portugal

virus nucleic acid in blood or CSF with RT-PCR or other Nucleic Acid Amplification Test (NAAT).

Pregnant women, patients with chronic diseases and with immunodeficiency were considered at particular risk of getting the disease and of possible complications.

As of 25 November 2012 (calendar week 47), seven weeks after the first autochthonous cases were identified, 1,891 probable cases of dengue fever have been reported, of which 966 were laboratory confirmed

Of the total number of 1,891 cases, 777 (41.1\%) were male and 1,114 (58.9\%) were female. The median age of the 1,891 cases was 39 years (range 25-64). Up to week 47 , the most affected age group was 25 to 64 years-old (Table).

One hundred and eleven patients were hospitalised and no fatalities were recorded. Of the total number of cases $(n=1,891)$, the majority had mild symptoms, with fever, myalgia, headaches and arthralgia.

Current geographic distribution of cumulative dengue cases by parish of residence is presented in Figure 2. The highest proportion of patients is recorded in residents of Santa Luzia parish.

As of 25 November, 29 cases of dengue fever were reported among travellers returning from Madeira. Twelve cases of dengue fever were recorded in travellers to mainland Portugal. In addition, 17 cases were detected in travellers returning to other European countries: United Kingdom $(n=6)$, Germany $(n=7)$, Sweden $(n=1)$, France $(n=2)$ and Finland $(n=1)$.

\section{Laboratory investigation}

Sequence analyses of viral genomes (600 nucleotides), performed at the National Institute of Health Dr. Ricardo Jorge, Lisbon, Portugal, presented high sequence similarity with DEN-1 viruses circulating in Venezuela and Colombia, suggesting Latin America as the possible origin for the circulating dengue virus [12].

\section{Entomological findings}

In 2006, a mosquito surveillance system based on ovitraps, traps that collect eggs by mimicking breeding sites, was established to monitor the presence and the abundance of the vector on the island [13]. By 2009, Ae. aegypti was detected outside Funchal city in the neighbouring localities of Câmara dos Lobos and Caniço. In September 2011, cross-sectional entomological surveys were carried out using a total of 273 ovitraps dispersed throughout Madeira (253 ovitraps) and Porto Santo islands (20 ovitraps). Results showed that the mosquito population had expanded to the west (Ponta do Sol and Ribeira Brava counties) and east of Funchal city (Santa Cruz county). The vector was also detected in Porto Moniz, but its presence was not confirmed in subsequent monitoring activities (unpublished data).

After the onset of the outbreak in October 2012, the surveillance network was reinforced and, currently, mosquito activity is monitored by 141 ovitraps and 16 BG-sentinel traps, traps baited with attractants to biting females. These traps are distributed mainly along the south coast of the island and in selected areas such as harbours, the airport, healthcare facilities and potential transmission zones. Up to date the vector has not been found on Porto Santo.

\section{Control measures}

In response to the outbreak, several control measures have been undertaken by the health authorities of Madeira. In order to prevent exportation, enhanced vector control measures have been implemented at Madeira's single airport. Currently, all aircrafts departing from the island undergo disinfestation procedures. Mosquito surveillance systems at the airport and at

\section{TABLE}

Notified dengue fever cases by age group, Madeira, Portugal, 3 October-25 November 2012 ( $\mathrm{n}=1,891)$

\begin{tabular}{|c|c|c|}
\hline Age group (years) & Number of cases & Percentage (\%) \\
\hline $0-14$ & 240 & 12.7 \\
\hline $15-24$ & 299 & 15.8 \\
\hline $25-64$ & 1,132 & 59.9 \\
\hline $65^{+}$ & 220 & 11.6 \\
\hline Total & 1,891 & 100 \\
\hline
\end{tabular}




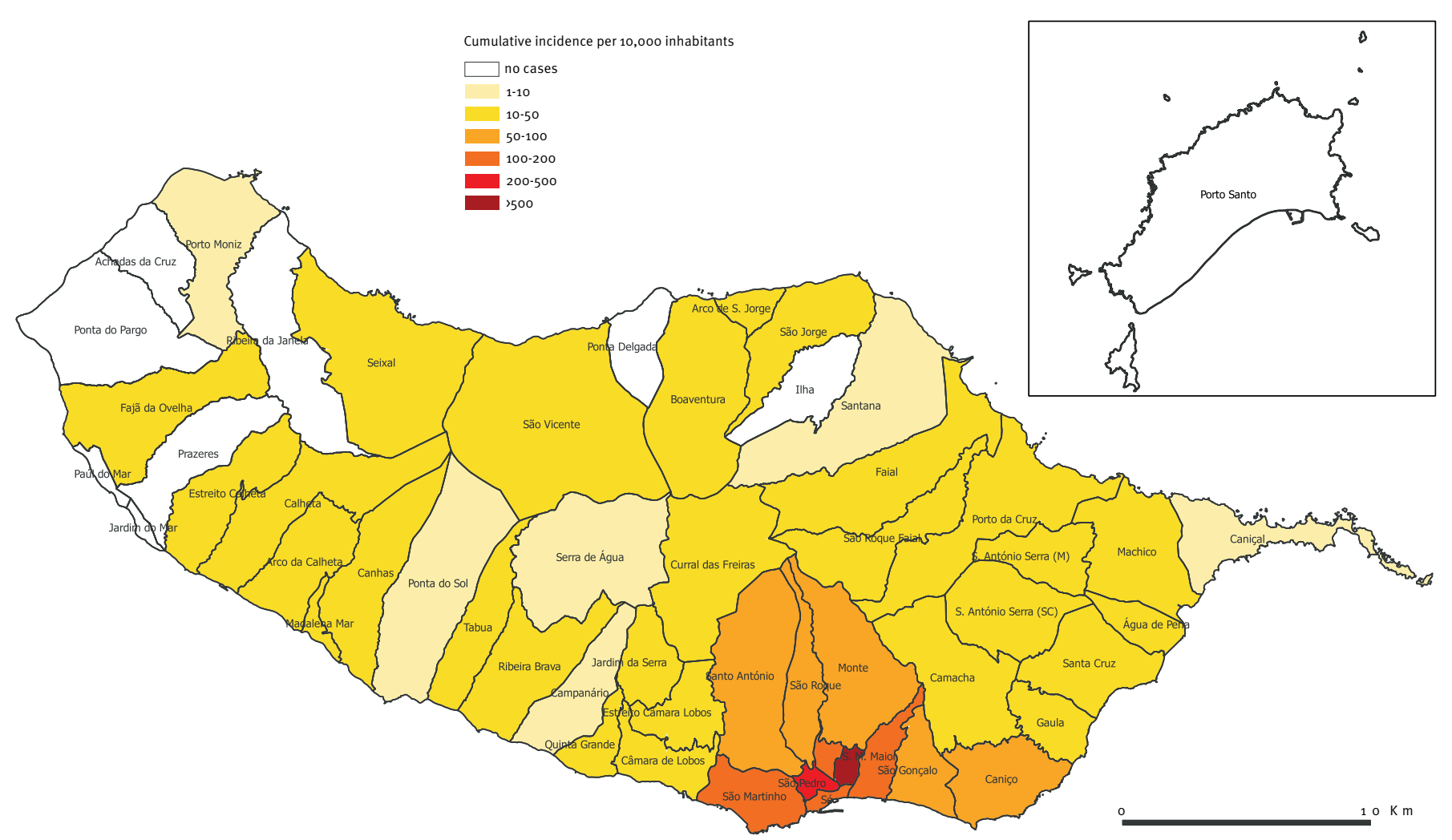

The map was created in Quantum GIS with support from the European Centre for Disease Prevention and Control.

passenger and cargo harbours have been boosted. Particular care is being given to the passenger ship port, located in the most affected area, Funchal. Information, mainly focused on the use of personal protective measures and on the elimination of mosquito breeding sites [14], is being disseminated by several mechanisms: (i) individual information to residents through a door-to-door campaign carried-out by environmental technicians of the IASAUDE, RAM; (ii) postings on IASAUDE website and in traditional and social media, and; (iii) community-based activities involving the educational, religious and health sectors. Advice for travellers to Madeira has been issued, containing information about methods to reduce the risk of being bitten by mosquitoes and symptoms of the disease [15].

Guidelines for diagnostic and management of dengue fever were provided to healthcare professionals. Measures to ensure blood safety and the safety of substances of human origin have been implemented and published since the detection of the first cases [16].

Nationwide measures to ensure blood safety in mainland Portugal included deferral of potential blood donors who visited Madeira island for a period of 28 days after leaving the affected area, deferral of potential blood donors with fever or influenza-like symptoms for 28 days after recovery, deferral of confirmed cases of dengue infection for 120 days after recovery and post transfusion haemovigilance.

Local measures applying to the blood services of the affected area included: (i) quarantine of all red cell concentrates resulting from blood collected during the previous 28 days and retrospective testing of relevant archived samples; (ii) deferral of blood donors with fever or influenza-like symptoms up to 28 days after recovery; (iii) deferral of confirmed dengue cases for 120 days after diagnosis; (iv) laboratory screening of all blood donations by RT-PCR for dengue virus; (v) information to blood donors to report any symptoms in the 15 days after donation; (vi) stop of local platelet production and supply of platelets from the Portuguese Institute for Blood and Transplants (Instituto Português de Sangue e Transplantes - IPST). Special attention is paid to the optimal use of blood, appropriate management of the blood supply and haemovigilance.

\section{Discussion}

The 2012 dengue outbreak on Madeira is the first of its kind in Europe since 1928. Given its magnitude and 
its potential public health impact in a European context, the European Centre for Disease Prevention and Control (ECDC) in Stockholm, Sweden, has, on request of the Portuguese authorities, deployed experts to Madeira to assist the regional and national authorities in investigating and controlling the outbreak and prevent further expansion within Europe.

While Ae. aegypti is not considered an established mosquito species in continental Europe, its presence has been sporadically reported in restricted areas in the Netherlands and Russia [17]. The present outbreak however, draws attention to the need to better assess the possibility of dengue epidemics mediated by $A e$. albopictus, that is present in several European countries. Besides the need to reinforce strategies aimed at averting the introduction of Ae. aegypti in Europe [18], it is also important to detect and monitor all imported human cases that might introduce the virus among a very competent mosquito species, Ae. albopictus.

At the time of publishing this report, the outbreak on Madeira is still ongoing. However, in week 48, the number of cases reported has decreased by around $54 \%$ (from 219 cases to 102 cases) when compared with the previous week. According to the weather forecast for the coming winter weeks, Madeira expects a decrease in temperature. This is assumed to have an impact on the vector, reducing its densities and, consequently, the number of dengue cases might further decline. Nevertheless, even in the absence of new reported human cases the virus may persist on the island either through vertical transmission or maintained by the small number of adult overwintering mosquito females.

Given the challenges posed by the dengue outbreak on Madeira, continued vigilance and a coordinated regional, national and international approach are needed.

\section{References}

1. European Centre for Disease Prevention and Control (ECDC) Factsheet for health professionals. Dengue fever. Stockholm: ECDC. [Accessed 4 Oct 2012]. Available from: http://ecdc. europa.eu/en/healthtopics/dengue fever/basic facts/Pages/ Factsheet_health_professionals.aspx

2. Halstead SB, Papaevangelou G. Transmission of dengue 1 and 2 viruses in Greece in 1928. Am J Trop Med Hyg. 1980;29(4):635-7.

3. Jelinek T. Trends in the epidemiology of dengue fever and their relevance for importation to Europe. Euro Surveill. 2009;14(25):pii=19250. Available from: http://www. eurosurveillance.org/ViewArticle.aspx?Articleld=19250

4. Gautret P, Simon F, Hervius Askling H, Bouchaud O, LeparcGoffart I, Ninove L, et al. Dengue type 3 virus infections in European travellers returning from the Comoros and Zanzibar, February-April 2010. Euro Surveill. 2010;15(15):pii=19541. Available from: http://www.eurosurveillance.org/ViewArticle. aspx?Articleld $=19541$

5. Nisii C, Carletti F, Castilletti C, Bordi L, Meschi S, Selleri M, et al. A case of dengue type 3 virus infection imported from Africa to Italy, October 2009. Euro Surveill. 2010;15(7): pii=19487. Available from: http://www.eurosurveillance.org/ViewArticle. aspx?Articleld $=19487$

6. Wichmann O, Gascon J, Schunk M, Puente S, Siikamaki H, Gjorup I, et al. Severe dengue virus infection in travelers: risk factors and laboratory indicators. J Infect Dis. 2007;195(8):1089-96.
7. La Ruche G, Souarès Y, Armengaud A, Peloux-Petiot F, Delaunay $P$, Desprès $P$, et al. First two autochthonous dengue virus infections in metropolitan France, September 2010. Euro Surveill. 2010;15(39):pii=19676. Available from: http://www. eurosurveillance.org/ViewArticle.aspx?Articleld=19676

8. Gjenero-Margan I, Aleraj B, Krajcar D, Lesnikar V, Klobučar A, Pem-Novosel I, et al. Autochthonous dengue fever in Croatia, August-September 2010. Euro Surveill. 2011;16(9):pii=19805. Available from: http://www.eurosurveillance.org/ViewArticle. aspx?Articleld $=19805$

9. Instituto Nacional de Estatística, Portugal. Censos 2011. Resultados Preliminares. [2011 Census. Preliminary results] Lisbon: Instituto Nacional de Estatística. [Accesed 4 Oct 2012]. Portuguese. Available from: http://www.ine.pt/scripts/flex_ definitivos/Main.html

10. Departamento de Producción de la Agencia Estatal de Meteorología de España (Área de Climatología y AplicacionesOperativas) y por el Departamento de Meteorologia e Clima, Instituto de Meteorologia de Portugal (Divisão de Observação Meteorológica e Clima). Atlas Climático dos arquipélagos das Canárias, da Madeira e dos Açores (1971-2000). [Climate Atlas of the Archipelagos of the Canary Islands, Madeira and the Azores (1971-2000)]. Lisbon: Instituto de Meteorologia de Portugal. 2011. Portuguese.

11. Almeida AP, Gonçalves YM, Novo MT, Sousa CA, Melim $M$, Gracio AJ. Vector monitoring of Aedes aegypti in the Autonomous Region of Madeira, Portugal. Euro Surveill. 2007;12(46): pii=3311. Available from: http://www. eurosurveillance.org/ViewArticle.aspx?Articleld=3311

12. National Institute of Health Dr. Ricardo Jorge. Febre de dengue na Madeira, Diagnóstico laboratorial. [Dengue fever in Madeira. Laboratory diagnosis]. Lisbon: National Institute of Health Dr. Ricardo Jorge. 9 Oct 2012. Available from: http:// www.insa.pt/sites/INSA/Portugues/ComInf/Noticias/Paginas/ DengueMadeiraDiagLab.aspx

13. Gonçalves Y, Silva J, Biscoito M. On the presence of Aedes (Stegomyia) aegypti Linnaeus, 1762 (Insecta, Diptera, Culicidae) in the island of Madeira (Portugal). Bol Mus Mun Funchal. 2008;58 (322):53-9

14. Serviço de Saúde da RAM. [Dengue fever: Personal protective measures]. Funchal: Serviço de Saúde da RAM. [Accessed 4 Oct 2012]. Portuguese. Available from: http://iasaude.sras. gov-madeira.pt/mosquitos/

15. Directorate-General of Health, Portugal. Comunicado do Diretor-Geral da Saúde com recomendações para os cidadãos que viajem para a llha da Madeira, na sequência dos casos de dengue reportados naquela região. [Notice of the Director General of Health with recommendations for citizens traveling to the island of Madeira, in the context of dengue fever cases reported in the region]. Lisbon: Directorate-General of Health. 9 Oct 2012. Portuguese. Available from: http://www.dgs.pt/

16. Directorate-General of Health. Casos de dengue na Regiao Autonoma da Madeira. Abordagem para casos de dengue. [Dengue cases in the Autonomous Region of Madeira. Approaching dengue cases]. Lisbon: Directorate-General of Health. 3 Oct 2012. Portuguese. Available from: http://www. dgs.pt/upload/membro.id/ficheiros/io17887.pdf

17. European Centre for Disease Prevention and Control [ECDC]. VBORNET Maps - Mosquitoes. Stockholm: ECDC. [Accessed 4 Oct 2012]. Available from: http://ecdc.europa.eu/en/activities/ diseaseprogrammes/emerging and vector borne diseases/ Pages/VBORNET_maps.aspx

18. European Centre for Disease Prevention and Control (ECDC). Guidelines for the surveillance of invasive mosquitoes in Europe. Technical report. Stockholm: ECDC. Aug 2012. Available from: http://ecdc.europa.eu/en/publications/ Publications/TER-Mosquito-surveillance-guidelines.pdf 